\title{
Propiconazole Inhibits Armillaria tabescens In Vitro and Translocates into Peach Roots Following Trunk Infusion
}

\author{
A. Amiri, Department of Entomology, Soils, and Plant Sciences, Clemson University, Clemson, SC 29634; Karen E. \\ Bussey, Department of Crop Science, North Carolina State University, Raleigh, NC 27619; and Melissa B. Riley and \\ G. Schnabel, Department of Entomology, Soils, and Plant Sciences, Clemson University
}

\begin{abstract}
Amiri, A., Bussey, K. E., Riley, M. B., and Schnabel, G. 2008. Propiconazole inhibits Armillaria tabescens in vitro and translocates into peach roots following trunk infusion. Plant Dis. 92:12931298.

Intravascular trunk infusion of propiconazole has been associated with beneficial effects on Armillaria root rot control in Prunus sp. but its basipetal movement has not been verified. Propiconazole, a sterol demethylation inhibitor fungicide, was more effective in inhibiting mycelial growth of Armillaria tabescens isolates in vitro (average effective concentration to inhibit mycelial growth by $50 \%$ [EC $\mathrm{EC}_{50}$ value] of $0.6 \mu \mathrm{g} / \mathrm{ml}$ ) compared with fungicides from five other chemical classes $\left(\mathrm{EC}_{50}\right.$ values ranging from 4.6 to $\left.>1,000 \mu \mathrm{g} / \mathrm{ml}\right)$. The fungicide was infused into the vascular system of peach trees in the spring, summer, and fall of 2005 and 2006. Propiconazole concentration was determined using gas chromatography mass spectrometry in trunk sections above and below the infusion site and in primary roots. Over two experimental years, spring and fall infusions resulted in consistent propiconazole accumulations in primary peach roots. Spring infusions yielded propiconazole concentrations of $1.7 \mu \mathrm{g} / \mathrm{g}$ in 2005 and $5.6 \mu \mathrm{g} / \mathrm{g}$ in 2006, whereas the highest accumulations were detected following fall infusions with $9.2 \mu \mathrm{g} / \mathrm{g}$ in 2005 and $6.7 \mu \mathrm{g} / \mathrm{g}$ in 2006. Propiconazole was also consistently detected in trunk sections collected from above and below the infusion site. The basipetal movement of propiconazole in peach trees and its inhibitory activity against $A$. tabescens in vitro suggest that propiconazole infusion could be useful for targeted Armillaria root rot management.
\end{abstract}

Armillaria root rot (ARR) caused by Armillaria spp. is a serious disease in many forests and horticultural tree crops worldwide. The fungus attacks plant roots, infecting and degrading the cambium and woody tissues $(33,37)$. The pathogen can survive for decades in the soil protected inside residual root fragments (8), and it spreads between trees by rhizomorphs or root-to-root contact. When forest areas infected with Armillaria spp. are converted into fruit tree orchards, infected roots that remain in the soil constitute the primary source of inoculum to infect newly planted trees. In the southeastern United States, home of the second largest peach production area in the country, the disease is caused mainly by Armillaria tabescens (Scop.) Dennis, Orton \& Hora, and constitutes one of the greatest threats to peach production in this region $(25,27)$.

Corresponding author: Guido Schnabel

E-mail: schnabe@clemson.edu

Technical Contribution No. 5451 of the Clemson University Experiment Station. This material is based upon work supported by the CSREES/ USDA, under project number SC-1000642.

Accepted for publication 5 May 2008.

doi:10.1094/PDIS-92-9-1293

(C) 2008 The American Phytopathological Society
Because the fungus is a soil inhabitant, it is difficult to control the disease using conventional management practices. In the absence of disease-resistant rootstocks, soil fumigation has been tested against ARR. Preplant fumigation with methyl bromide has been marginally effective $(26,29)$ and other fumigants such as chloropicrin (14), isothiocyanate (12), carbon disulfide (13), and sodium tetrathiocarbonate (1) have been shown to reduce but rarely eradicate Armillaria propagules. In a recent study of grapevines, the sterol demethylation inhibitor (DMI) fungicide cyproconazole, which is effective against $A$. mellea in vitro, did not reduce disease severity when applied at $500 \mu \mathrm{g} / \mathrm{ml}$ as a basal soil drench (2).

Intravascular chemical infusion for disease control has been attempted in a range of woody plants using different chemicals. In order to control eastern $\mathrm{X}$-disease in peach trees, oxytetracycline hydrochloride was successfully injected into peach trees by gravity flow infusion or by pipettes (20). Furthermore, early fall trunkinjections of Lignasan BLP (methyl 2benzimidazole carbamate phosphate) protected elm trees from Dutch elm disease caused by Ophiostoma ulmi throughout the highly susceptible phase of their annual growth cycle (10). It has been shown that intravascular injection of propiconazole reduced the incidence of Ceratocystis $\mathrm{fa}$ - gacearum in live (Quercus virginiana), red (Q. rubra), and pin ( $Q$. palustrus) oak stands for up to 36 months $(3,23)$.

Intravascular chemical applications have been investigated for ARR management in Prunus spp. as well. Control of A. luteobubalina on stone fruit was reported using trunk injections of phosphonate (16). Passive infusions of propiconazole into 7to 8-year-old Armillaria spp.-infected almond (Prunus dulcis) trees grown on peach rootstocks reduced mortality compared with controls over a 2-year period (1). Although some fungicides such as phosphonates are believed to induce systemic acquired resistance in the host, DMI fungicides such as propiconazole require uptake by the pathogen for fungicidal action. Because few fungicides are known to be phloem mobile $(9,30)$, we evaluated the downward movement of propiconazole to peach roots. Such data could explain a previous report on propiconazole efficacy (1) and lead to improved application timings, rates, and techniques, thereby improving ARR management.

The goal of this study was to evaluate intravascular applications of propiconazole as a possible management practice for ARR of peach. We determined the activity of propiconazole and other fungicides against $A$. tabescens in vitro and investigated the basipetal movement of propiconazole following trunk infusion.

\section{MATERIALS AND METHODS}

Isolates. Two isolates of $A$. tabescens were used to determine the activity of propiconazole and other fungicides in vitro. Isolate SC.MF-101 was collected in 2001 from a dying peach tree at Clemson University-Musser Fruit Research Farm, Seneca, SC and isolate GA.00i210 was collected from peach tree roots in Watkinsville, GA in 2000. The isolates were maintained on $2 \%$ malt extract agar medium (MEA) under sterile mineral oil (Cumberland Swan, Smyrna, TN) in glass screw-top tubes at $4^{\circ} \mathrm{C}$.

Fungicides. To select a suitable fungicide active against $A$. tabescens, nine formulated commercial products belonging to eight different chemical classes were tested in vitro (Table 1). Active ingredients were azoxystrobin (Abound 2.08F; Syngenta Crop Protection Inc., Greensboro, NC), boscalid (Endura; BASF Corp., Research Triangle Park, NC), carboxin and thiram 
(Vitavax M; Uniroyal Chemical Co. Inc., Middlebury, CT), propiconazole (Orbit 3.6E; Syngenta), cyprodinil (Vangard 75WG; Syngenta), copper sulfate pentahydrate (Phyton 27; Phyton Corp., New Hope, MN), copper mixed with mancozeb (Cuprofix MZ Disperss; Cerexagri Inc., King of Prussia, PA), phosphorous acid (Kphite; Plant Food Systems, Zellwood, FL), and $O$-ethyl phosphonate (Aliette WDG; Bayer CropScience, Research Triangle Park, NC). The concentration of active ingredient $(\%)$ in each formulation is shown in Table 1.

In vitro activity of fungicides against A. tabescens. In vitro sensitivity of the two A. tabescens isolates to fungicides was determined by measuring relative mycelial growth on fungicide-amended medium. Cyprodinil was tested on a minimal medium $\left(\mathrm{KH}_{2} \mathrm{PO}_{4}\right.$ at $1.75 \mathrm{~g} / \mathrm{liter}, \mathrm{MgSO}_{4}$ at $0.75 \mathrm{~g} /$ liter, glucose at $4.0 \mathrm{~g} / \mathrm{liter}$, and agar at $4.0 \mathrm{~g} /$ liter) as previously described (5). All other fungicides were tested on $3 \%$ MEA enriched with $3 \%$ glucose and $1 \%$ peptone. To inhibit the alternative oxidase pathway, salicylhydroxamic acid (SHAM) was added to azoxystrobin-amended medium at $100 \mu \mathrm{g} / \mathrm{ml}$ (28). Media were amended with fungicides to final concentrations of $0.03,0.1,0.3,1,5,100,300$, and $1,000 \mathrm{mg} /$ liter. Copper sulfate was tested only at concentrations up to 300 $\mathrm{mg} / \mathrm{liter}$.

Agar plugs (6 $\mathrm{mm}$ in diameter) were taken from the periphery of 14-day-old MEA cultures and transferred to fungicideamended and nonamended media. Plates were sealed with parafilm and incubated in the dark for 14 days at $25^{\circ} \mathrm{C}$. Percent inhibition of growth compared with controls was calculated and the effective concentration to inhibit mycelial growth by $50 \%$ ( $\mathrm{EC}_{50}$ values) was determined as described in the "data analysis" section. Five replicate plates were assessed for each isolatefungicide concentration combination. The entire experiment was conducted twice.

Experimental orchard. Field experiments were conducted at the Musser Fruit Research Farm, Seneca, SC, on cv. Redskin peach trees on Guardian rootstock planted in 1995. The experimental orchard consisted of a block of 135 trees. For each experiment, four trees with $20-$ to $25-\mathrm{cm}$ trunk diameter were randomly selected for each treatment. As part of the general pest and disease maintenance sprays, this orchard received two applications of propiconazole (Orbit $3.6 \mathrm{E}$ at $287 \mathrm{ml} / \mathrm{ha}$ ) on 29 July and 8 August 2005.

Infusion of propiconazole into peach trees using the "infusion tube" delivery device. Nonpressurized intravascular infusion was performed at three applicationtimes during two successive years (Table 2) to transfer the fungicide to the vascular tissue of the tree. Meteorological data (i.e. temperature and humidity relative values recorded during the three days of infusion; weather station. Propiconazole formulated as Orbit 3.6E was infused in the spring and summer of 2005, whereas propiconazole formulated as Alamo was used in the fall of 2005 and for all treatments in 2006. Orbit is an emulsifiable concentrate (EC) containing $41.8 \%$ propiconazole whereas Alamo is a suspension concentrate (SC) containing $14.3 \%$ propiconazole without any toxic organic solvents. Infusion tubes consisted of a flexible plastic tube (2.54$\mathrm{cm}$ inner diameter) with a nylon barb adapter $(1.27$ by $0.635 \mathrm{~cm})$. Each tube was long enough (approximately $1.2 \mathrm{~m}$ ) to hold $400 \mathrm{ml}$ of solution. For fungicide infusions, five holes $(0.64 \mathrm{~cm}$ in diameter and 1.0 to $1.5 \mathrm{~cm}$ deep) were drilled 12 to 15 Table 2) were obtained from the local

$\mathrm{cm}$ above the soil line at $10-\mathrm{cm}$ intervals around the circumference of each tree trunk using an electric drill. Five infusion tubes were tied to scaffold branches of each tree and the nylon adapters (Watts Anderson-Barrows, Palmdale, CA) were inserted into the five predrilled holes. In all, 2 liters of a propiconazole solution (40 $\mathrm{mg} / \mathrm{liter}$ ) and 2 liters of tap water were infused into fungicide-treated or control trees, respectively. After 24 h, empty infusion tubes were removed and holes were left uncorked. Experimental trees were excavated $48 \mathrm{~h}$ following treatments using a front-end loader. Pieces of primary roots (10 to $15 \mathrm{~cm}$ long and 2 to $3 \mathrm{~cm}$ in diameter) were arbitrarily collected within 30 to $50 \mathrm{~cm}$ of the infusion site. In addition, trunk cross-sections $(2.5$ to $5 \mathrm{~cm}$ in thickness) were harvested 2 to $5 \mathrm{~cm}$ above and below the infusion site using a chainsaw. Root and trunk sections were stored at $-20^{\circ} \mathrm{C}$ until analysis was performed.

Preparation of propiconazole standards. For quantitative gas chromatography mass spectrometry (GC-MS) analysis, a stock solution of propiconazole (200 $\mu \mathrm{g} / \mathrm{ml}$ ) was prepared by dissolving propiconazole analytical propiconazole (Tilt 97.2\%; Chemical Service Inc., West Chester, PA) in acetonitrile. Appropriate propiconazole dilutions $(1,10,100$, and 200 $\mu \mathrm{g} / \mathrm{ml})$ were made in methanol and stored in glass vials at $-20^{\circ} \mathrm{C}$. Acetonitrile and methanol (99.9\% purity for GC analysis)

Table 2. Mean temperature and humidity levels from the time of infusion until harvest of roots and trunk sections $^{y}$

\begin{tabular}{|c|c|c|c|c|c|c|c|}
\hline \multirow[b]{2}{*}{ Year, season $^{\mathrm{z}}$} & \multirow[b]{2}{*}{ Application date } & \multicolumn{3}{|c|}{ Temperature $\left({ }^{\circ} \mathbf{C}\right)$} & \multicolumn{3}{|c|}{ Relative humidity (\%) } \\
\hline & & D & $D+1$ & $\mathrm{D}+2$ & D & $D+1$ & $\mathrm{D}+2$ \\
\hline \multicolumn{8}{|l|}{2005} \\
\hline Spring & 4 May & 14.6 & 14.4 & 17.8 & 68.2 & 76.5 & 64.3 \\
\hline Summer & 6 July & 25.2 & 22.6 & 25.5 & 88.4 & 74.2 & 93.6 \\
\hline Fall & 24 October & 11.8 & 10.8 & 10.8 & 64.7 & 64.3 & 69.5 \\
\hline \multicolumn{8}{|l|}{2006} \\
\hline Spring & 15 May & 15.7 & 15.5 & 16.5 & 68.1 & 71.5 & 70.7 \\
\hline Summer & 7 July & 23.4 & 23.4 & 23.6 & 75.6 & 73.1 & 75.8 \\
\hline Fall & 29 October & 16.1 & 16.0 & 13.5 & 69.8 & 69.2 & 80.5 \\
\hline
\end{tabular}

y Temperature and relative humidity on the day of infusion (D), $24 \mathrm{~h}$ later $(\mathrm{D}+1)$, and $48 \mathrm{~h}$ later (sampling day; $\mathrm{D}+2$ ).

${ }^{z}$ Propiconazole formulated as Orbit was infused in spring and summer 2005. Propiconazole formulated as Alamo was infused in fall 2005 and at all application dates in 2006.

Table 1. Sensitivity $\left(\mathrm{EC}_{50}\right)$ of two Armillaria tabescens isolates to fungicides from six different chemical groups

\begin{tabular}{|c|c|c|c|c|c|}
\hline \multirow[b]{2}{*}{ Fungicide formulation } & \multirow[b]{2}{*}{ Active ingredient } & \multirow[b]{2}{*}{ a.i. $(\%)$} & \multirow[b]{2}{*}{ Chemical group } & \multicolumn{2}{|c|}{$\mathrm{EC}_{50}(\mu \mathrm{g} / \mathrm{ml})^{\mathrm{z}}$} \\
\hline & & & & GA.00i210 & SC.MF-101 \\
\hline Abound $2.08 \mathrm{~F}$ & Azoxystrobin & 22.9 & Quinone outside inhibitor & $>1,000 \mathrm{a}$ & $>1,000 \mathrm{a}$ \\
\hline Endura & Boscalid & 70.0 & Pyridine carboxamide & $>1,000 \mathrm{a}$ & $>1,000 \mathrm{a}$ \\
\hline Vitavax M & Carboxin/thiram & $5.7 / 5.7$ & Oxathiin carboxamide/dithiocarbamate & $4.6 \pm 0.1 \mathrm{c}$ & $13.7 \pm 4.4 \mathrm{c}$ \\
\hline Orbit 3.6E & Propiconazole & 41.8 & Sterol demethylation inhibitor & $0.6 \pm 0.2 \mathrm{~d}$ & $0.6 \pm 0.3 \mathrm{~d}$ \\
\hline Vanguard $75 \mathrm{WG}$ & Cyprodinil & 75.0 & Anilino-pyrimidine & $>1,000 \mathrm{a}$ & $>1,000 \mathrm{a}$ \\
\hline Phyton 27 & Copper sulfate & $21 / 4$ & Inorganic & $>300 \mathrm{~b}$ & $>300 \mathrm{~b}$ \\
\hline Cuprofix MZ Disperss & Copper sulfate/mancozeb & $22.1 / 30.4$ & Inorganic/dithiocarbamate & $>1,000 \mathrm{a}$ & $>1,000 \mathrm{a}$ \\
\hline Kphite & Phosphorous acid & 53.0 & Phosphonate & $>1,000 \mathrm{a}$ & $>1,000 \mathrm{a}$ \\
\hline Aliette WDG & $O$-ethyl phosphonate & 80.0 & Phosphonate & $>1,000 \mathrm{a}$ & $>1,000 \mathrm{a}$ \\
\hline
\end{tabular}

${ }^{\mathrm{z}} \mathrm{EC}_{50}=$ effective concentration of active ingredient necessary to inhibit 50\% of the mycelial growth. Data are means of 10 replications across two experimental runs. Mean values marked with different letters are significantly different based on analysis of variance and Fisher's least significant difference ( $\alpha=$ $0.05)$. 
were purchased from Burdick \& Jackson, Muskegon, MI.

Quantitative analysis of propiconazole in root and trunk sections. Root and trunk sections were removed from storage $\left(-20^{\circ} \mathrm{C}\right)$ and allowed to thaw for 3 to $4 \mathrm{~h}$ at room temperature prior to fungicide extraction. Samples were brushed to remove adherent soil, briefly washed under tap water, and dried under a laminar flow hood for $10 \mathrm{~min}$. The primary roots and the inner bark and cambium tissues from trunk sections were then cut into small pieces using garden shears. All glassware used for extractions was silinized.

To determine percent recovery, peach root samples (10 g each) collected from noninfused trees were spiked with a propiconazole standard prior to extraction. For this, 500, 300, 200, and $50 \mu \mathrm{l}$ of the propiconazole stock solution (200 $\mu \mathrm{g} / \mathrm{ml}$ ) was distributed on the samples. To allow methanol evaporation and internal distribution of propiconazole, the spiked tissues were dried overnight under a hood, resulting in final concentrations of propiconazole at $10,6,4$, and $1 \mu \mathrm{g} / \mathrm{g}$ of root tissue. Three samples per concentration were extracted and the test was conducted twice.

Propiconazole was extracted by homogenizing each tissue sample in $50 \mathrm{ml}$ of methanol for $5 \mathrm{~min}$ using a Polytron homogenizer (Brinkmann Instrument, Westbury, NY). Samples were then shaken overnight (at $200 \mathrm{rpm}$ ) on an orbital shaker (Environ Shaker; LAB-LINE Instruments, Inc., Melrose Park, IL). The homogenized mixture was filtered under vacuum through no. 1 filter paper (Whatman International Ltd., Kent, UK) and transferred to glass vials ( 27 by $95 \mathrm{~mm}$ ) with two-holed rubber stoppers. The vials were placed in a water bath at $45^{\circ} \mathrm{C}$ and the filtrate was evaporated to dryness by blowing a gentle stream of nitrogen through one hole of the stopper. Samples were resuspended in $4 \mathrm{ml}$ of hexane (Burdick \& Jackson) + acetone $(5+1 \mathrm{vol} / \mathrm{vol})(6)$ and shaken for $5 \mathrm{~min}$. A portion of the top layer $(3 \mathrm{ml})$ was removed and transferred to a $15-\mathrm{ml}$ conical glass test tube. This fraction was evaporated to $1 \mathrm{ml}$ as above and stored at $-20^{\circ} \mathrm{C}$ overnight to allow precipitants to settle out. An aliquot of the supernatant $(900 \mu \mathrm{l})$ was then transferred to GC vials for analysis. Three samples from each tissue were analyzed for each tree.

GC-MS. Samples were analyzed on a Hewlett-Packard 5890 gas chromatograph (Agilent Technologies, Wilmington, DE) coupled to an HP 5971A mass selective detector. The GC-MS was equipped with an Ultra 2 column $(25 \mathrm{~m}$ by $0.2 \mathrm{~mm}$ inner diameter, $0.33 \mu \mathrm{m}$ film thickness; Agilent Technologies). Sample injections $(3 \mu \mathrm{l})$ were splitless for 2 min followed by a split of $60: 1$. Analysis was performed with the following specifications: the flow rate of helium carrier gas was $0.5 \mathrm{ml} / \mathrm{min}$, injector temperature was $250^{\circ} \mathrm{C}$; initial oven temperature was $180^{\circ} \mathrm{C}$ with a ramp temperature of $15^{\circ} \mathrm{C} / \mathrm{min}$ to $300^{\circ} \mathrm{C}$ held for $10 \mathrm{~min}$, and solvent delay on the mass spectrometer was $3.5 \mathrm{~min}$. Single-ion monitoring was used for quantification using $\mathrm{m} / \mathrm{z} 173$ and 259 based on the mass spectrum of a standard concentration of propiconazole at 200 $\mu \mathrm{g} / \mathrm{ml}$.

Propiconazole concentrations $(\mu \mathrm{l} / \mathrm{g})$ in root and trunk sections were obtained by computing the peak area values obtained from the chromatograms from the samples and the concentration was calculated according to the equation resulting from the standard curve of stock solutions. Concentrations were divided by 10 to convert values for propiconazole $(\mu \mathrm{g})$ per gram of sample tissue, divided by 0.75 to correct for using only $3 \mathrm{ml}$ of the final extract, and divided by the average percent recovery to obtain the final concentration of propiconazole per sample.

Data analysis. For each fungicide tested in vitro, $\mathrm{EC}_{50}$ values were determined from regressions of the indices of effectiveness on the logarithms of fungicide concentrations. Data from field experiments were expressed as concentration of propiconazole $(\mu \mathrm{g})$ per gram of tissue sample (independently of the formulation). Data were analyzed separately for each year with two- and three-way multivariate analyses of variance and least significant difference procedure to determine specific differences among treatment means. All statistical tests were used at significance level of 0.05 , and all statistical calculations were performed using STATISTICA software (version 6.0; Statsoft Inc, Tulsa, OK).

\section{RESULTS}

In vitro activity of fungicides against A. tabescens. Mycelial growth of A. tabescens isolates was not inhibited or was only slightly inhibited by the majority of the nine fungicides tested (Table 1). For six of the active ingredients tested (i.e., azoxystrobin, boscalid, cyprodinil, copper sulfate mixed with mancozeb [Cuprofix MZ Dispress], phosphorous acid, and $O$-ethyl phosphate), $\mathrm{EC}_{50}$ values were greater than $1,000 \mu \mathrm{g} / \mathrm{ml}$. With another formulation of copper sulfate (Phyton 27), an $\mathrm{EC}_{50}$ value of $300 \mu \mathrm{g} / \mathrm{ml}$ was obtained. Both isolates of A. tabescens GA.00i210 and SC.MF101 were sensitive to the carboxin/thiram mixture, with $\mathrm{EC}_{50}$ values of 4.6 and 13.7 $\mu \mathrm{g} / \mathrm{ml}$, respectively. The most active compound against $A$. tabescens was propiconazole with an $\mathrm{EC}_{50}$ value of $0.6 \mu \mathrm{g} / \mathrm{ml}$ for both isolates (Table 1). Based on these results, propiconazole was selected for the field infusion study.

Gas chromatographic analysis and recovery. The selected equipment settings resulted in a retention time of approximately $9.5 \mathrm{~min}$ for propiconazole. Percent recovery of propiconazole from tissue samples decreased with decreasing rates of spiked fungicide (concentration of propiconazole in $\mu \mathrm{g} / \mathrm{g}$ of tissue) and there was a linear correlation $\left(R^{2}=0.94\right)$ in recovery between spiking levels of 1 and $10 \mu \mathrm{g} / \mathrm{g}$ of tissue (Fig. 1). Thus, the average recovery of propiconazole was 52, 61, 65, and $89 \%$ for spiking levels of $1,4,6$, and $10 \mu \mathrm{g} / \mathrm{g}$, respectively (Fig. 1).

Environmental conditions and propiconazole concentration in root and trunk sections. The environmental conditions (i.e., temperature and humidity lev-

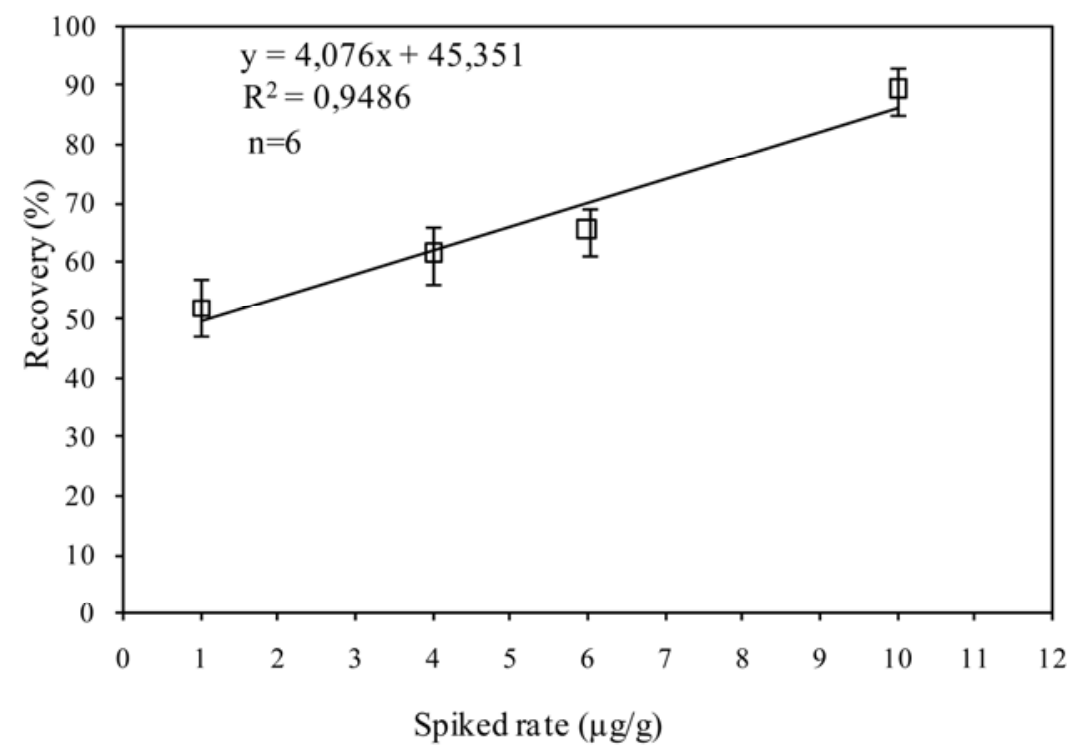

Fig. 1. Correlation between spiked rates and percent recovery from blank peach tissues spiked with different concentrations of propiconazole. Predetermined volumes of propiconazole solution diluted to $200 \mu \mathrm{g} / \mathrm{ml}$ with acetonitrile were added to root samples (10 g) to obtain the corresponding propiconazole concentration $(1,4,6$, or $10 \mu \mathrm{g} / \mathrm{g})$ and dried overnight to allow evaporation of solvent and extra water before extraction. Data points are the mean of six replications across two experimental runs. Vertical bars indicate standard deviation. 
els) were similar between 2005 and 2006, with the exception that temperatures were 3 to $6^{\circ} \mathrm{C}$ higher in fall 2006 (Table 2). Season, treatment, and season-treatment were significant effects in the multivariate analysis of variance (Table 3), indicating that the treatment effect on concentration of propiconazole in root and trunk sections varied between seasons. Even though there were no significant year effects, experimental years are shown separately because different formulations of propiconazole were used between years. Propiconazole concentrations in root and trunk sections that were harvested $48 \mathrm{~h}$ after infusion in three seasons of two consecutive years are shown in Table 4. Concentrations were significantly $(P<0.05)$ higher in primary roots of fungicide-infused trees compared with the corresponding controls following infusion in the spring and fall of both experimental years. Summer infusion in 2006 resulted in significantly higher propiconazole accumulation in root sections compared to the summer infusion in 2005 . Overall, propiconazole concentration in primary roots was highest following fall infusion in both experimental years. Relatively high concentrations of propiconazole were also found in root sections following spring infusions in 2006. Propiconazole concentrations in trunk sections below and above the infusion sites were consistently increased compared with the water-infused controls at all application timings of both experimental years, with the exception of above-trunk sections in fall 2005. The highest concentrations were found in below-trunk sections following spring infusions (propiconazole at 83.1 and $170.3 \mu \mathrm{g} / \mathrm{g}$ in 2005 and 2006, respectively; Table 4).

\section{DISCUSSION}

Among fungicides we tested in vitro, propiconazole was most effective against A. tabescens. To our knowledge, this is the first study evaluating the efficacy of fungicides from different chemical classes for this particular species of Armillaria. These results are consistent with a previous study showing an $\mathrm{EC}_{50}$ value for propiconazole of $0.15 \mu \mathrm{g} / \mathrm{ml}$ for A. mellea isolates (1). However, other studies reported lower efficacy $\left(\mathrm{EC}_{50}\right.$ value of $\left.6.2 \mu \mathrm{g} / \mathrm{ml}\right)$ for propiconazole against $A$. mellea (2). The carboxin/thiram mixture formulated as Vitavax $M$ was somewhat effective, with $\mathrm{EC}_{50}$ values ranging from 4.6 to 13.7 $\mu \mathrm{g} / \mathrm{ml}$. The activity of carboxin and thiram against $A$. tabescens was not evaluated separately but this mixture may have potential to control ARR.

Propiconazole translocation into the roots following trunk infusion was documented in this study. Numerically, roots from all propiconazole-infused trees contained more propiconazole compared with the water-infused trees, and consistent significant differences were observed in both experimental years following spring and fall infusions. These results offer a plausible explanation for the successful treatment of ARR of almond on peach rootstock and oak wilt of live oak following trunk injections with propiconazole $(1,3)$. The GC-MS analysis showed propiconazole concentrations of 6 to $9 \mu \mathrm{g} / \mathrm{g}$ in

Table 3. Multivariate analysis of variance for the impact of principal parameters on the concentration of propiconazole in roots and trunk sections of peach trees

\begin{tabular}{lcccc}
\hline Source & Sum of squares & df & $\boldsymbol{F}$ & $\boldsymbol{P}$ \\
\hline Year & 1,450 & 1 & 0.53632 & 0.46437 \\
Season & 29,586 & 2 & 5.47007 & 0.00452 \\
Treatment & 49,833 & 1 & 18.42666 & 0.00002 \\
Year $\times$ treatment & 887 & 1 & 0.32781 & 0.56726 \\
Season $\times$ treatment & 25,606 & 2 & 4.73411 & 0.00926 \\
Year $\times$ treatment $\times$ season & 5,852 & 2 & 1.08196 & 0.33987 \\
\hline
\end{tabular}

roots of Alamo-infused trees, which is more than 10 times higher compared with its $\mathrm{EC}_{50}$ value $(0.6 \mu \mathrm{g} / \mathrm{ml})$. Consequently, trunk infusions as conducted in this study may be successful in controlling A. tabescens in peach roots.

Low levels of propiconazole were detected in roots and trunk sections from water infused-trees. That might be explained by the fact that this fungicide is used as a standard material for blossom blight and preharvest brown rot control and it was sprayed in the test orchard in 2005. With a documented half-life ranging from 227 to 336 days in clay loam soils $(6,34)$, propiconazole may persist long enough in the soil to be taken up in small amounts by the roots or in trunks and scaffold limbs.

Propiconazole concentrations in roots of trees infused with Alamo in the spring and summer of 2006 were numerically higher compared with trees infused with Orbit at the corresponding periods in 2005. It seems likely that the Alamo formulation is better suited for propiconazole translocation compared with the Orbit formulation. Alamo is formulated as a microencapsulated SC to make it soluble in any clean water near neutral $\mathrm{pH}$ and is specifically registered for tree injections against oak wilt, Dutch elm disease, sycamore anthracnose, and various leaf diseases. Orbit is an emulsifiable concentrate containing petroleum distillates that render it less soluble in plant tissue, and probably less translocatable.

The process of propiconazole translocation from the trunk into roots is not yet understood. Generally, systemic fungicides are translocated within the host either for a short distance in the parenchyma or for a long distance in the flow of solutions trough the xylem, phloem, or both (ambisystemic) (19). However, several factors such as $\mathrm{pH}$, chemical structure (21), initial uptake by the tree, soil water content, and environmental conditions (15) might affect the translocation of fungicides. Neither xylem nor phloem translocations of propi-

Table 4. Propiconazole concentration in peach root and trunk sections following intravascular infusion

\begin{tabular}{|c|c|c|c|c|c|c|}
\hline \multirow[b]{3}{*}{ Season, treatment ${ }^{\mathrm{z}}$} & \multicolumn{6}{|c|}{ Propiconazole concentration $(\mu \mathrm{g} / \mathrm{g}) \pm \mathrm{SE}^{\mathrm{y}}$} \\
\hline & \multicolumn{3}{|c|}{2005} & \multicolumn{3}{|c|}{2006} \\
\hline & Root & Trunk below & Trunk above & Root & Trunk below & Trunk above \\
\hline \multicolumn{7}{|l|}{ Spring } \\
\hline Water & $0.06 \pm 0.01 \mathrm{c}$ & $0.7 \pm 0.3 \mathrm{c}$ & $0.7 \pm 0.3 \mathrm{~d}$ & $0.1 \pm 0.1 \mathrm{c}$ & $0.8 \pm 0.2 \mathrm{~cd}$ & $0.5 \pm 0.2 \mathrm{~d}$ \\
\hline Propiconazole & $1.7 \pm 0.7 \mathrm{~b}$ & $83.1 \pm 19.3 \mathrm{a}$ & $8.7 \pm 2.1 \mathrm{~b}$ & $5.6 \pm 2.7 \mathrm{a}$ & $170.3 \pm 12.2 \mathrm{a}$ & $13.6 \pm 2.9 \mathrm{~b}$ \\
\hline \multicolumn{7}{|l|}{ Summer } \\
\hline Water & $0.7 \pm 0.5 \mathrm{~b}$ & $0.3 \pm 0.1 \mathrm{c}$ & $1.9 \pm 0.7 \mathrm{c}$ & $0.2 \pm 0.2 \mathrm{c}$ & $1.0 \pm 0.4 \mathrm{c}$ & $0.3 \pm 0.1 \mathrm{~d}$ \\
\hline Propiconazole & $1.5 \pm 0.9 \mathrm{~b}$ & $20.5 \pm 3.0 \mathrm{~b}$ & $29.5 \pm 20.3 \mathrm{a}$ & $2.5 \pm 1.1 \mathrm{~b}$ & $7.4 \pm 1.3 b$ & $1.8 \pm 0.8 \mathrm{c}$ \\
\hline \multicolumn{7}{|l|}{ Fall } \\
\hline Water & $0.06 \pm 0.01 \mathrm{c}$ & $0.7 \pm 0.2 \mathrm{c}$ & $0.5 \pm 0.3 \mathrm{~d}$ & $0.1 \pm 0.1 \mathrm{c}$ & $0.3 \pm 0.1 \mathrm{~d}$ & $1.7 \pm 0.4 \mathrm{c}$ \\
\hline Propiconazole & $9.2 \pm 3.2 \mathrm{a}$ & $27.2 \pm 11.8 \mathrm{~b}$ & $1.3 \pm 0.6 \mathrm{~cd}$ & $6.7 \pm 2.8 \mathrm{a}$ & $4.1 \pm 8.7 b$ & $20.7 \pm 2.9 \mathrm{a}$ \\
\hline
\end{tabular}

y Mean propiconazole concentration and standard error (SE) of four replicate trees with three samples per tree. Mean values within each column marked with different letters are significantly different $(P<0.05)$ according to the least significant difference test. Propiconazole formulated as Orbit was infused in spring and summer 2005; propiconazole formulated as Alamo was infused at all other dates. Trunk below and Trunk above indicate that samples were taken 2 to $5 \mathrm{~cm}$ below and above the infusion site, respectively.

z Application season and type of infusion. 
conazole are documented in the literature; however, in a recent study, propiconazole was hypothesized to move downward when functioning xylem elements are broken by the injection wound, causing the injected solution to move either upward or downward, depending on the forces (negative pressure) within the xylem elements at the time of injection (32). Xylem transport is driven by a combination of transpirational pull from above and root pressure from below and it is mostly regulated by transpiration and to a lesser degree by the cohesive characteristics of water (38). Propiconazole might be mostly transported upward in the summer when transpiration is at its highest level, assuming that xylemmobile substances do not or rarely undergo downward movement. On the other hand, fungicides are translocated only together with photosynthates to sites of assimilate demand within the phloem. About $10 \%$ of labeled oxycarboxin applied as foliar spray on almond, chestnut, and peach was recovered from stems and roots (18). Downward translocation through the phloem has been reported for fosetyl-Al (22), benomyl (4), and thiabendazole (35). Additionally, in deciduous trees of temperate zones, there is a general downward movement of carbohydrate reserves which are translocated to the cambium of roots and stems in late summer and early autumn. It is possible that the high levels of propiconazole observed in peach roots in the fall in this study might have benefited from this general downward movement occurring at this period of the year.

In preliminary studies, pressurized injection systems (i.e., Sidewinder Standard Backpack Tree injector, a macro-infusion system and a systemic tree injection tube) were unable to deliver fungicides into mature peach trees (7) but they have been used successfully for a number of other tree species $(11,17,24)$. A possible reason for the failure of pressurized injection systems applied to peach trees could be due to the anatomical features of Prunus wood. $P$. persica has semi-ring-porous to diffuse-porous wood with solitary pores, whereas trees such as elm, ash, and oak, all of which have successfully been injected with pressurized systems, have ring-porous wood with pores situated in rows (31). Difficulties injecting peach trees was described earlier when low-pressure injections (59.98 to $79.98 \mathrm{kPa}$ ) of $250 \mathrm{ml}$ of water were tested on 23 different species, including peach, elm, eastern sycamore, and Holm oak (36). Results showed uptake rates for elm, sycamore, and oak to be within $1 \mathrm{~h}$ and rates for peach exceeding $48 \mathrm{~h}$.

In a separate experiment, we sprayed a mixture of Alamo and bark-penetrating surfactant Pentrabark (Agrichem Industries PTY Ltd., Queensland, Australia) to saturation in the spring and fall of 2006 to the trunk and scaffold limbs at the rates of
30.0 and $22.6 \mathrm{ml} / \mathrm{liter}$, respectively. After 2 days, there was no increase in propiconazole concentrations in root sections from trees sprayed with the mixture compared with water-sprayed trees (data not shown).

Trunk infusion of peach trees with propiconazole may have a place in ARR management strategies. It may not be economically feasible to conduct this treatment on a large scale; however, it could be useful to inhibit spread of expanding infection centers. Infection centers emerge in almost all southeastern peach orchards because the fungus is endemic to this region. Trunk infusions of trees surrounding infection centers might be useful in arresting the spread of the disease. Further studies are needed to correlate the basipetal movement of propiconazole to roots with its activity against Armillaria spp. under field conditions and to determine the persistence of propiconazole in peach roots.

\section{ACKNOWLEDGMENTS}

This research was funded in part by the South Carolina Peach Council, United States Department of Agriculture (USDA)-CSREES S-RIPM grant no. 2005-34103-15588, and the USDA-CSREES special grant no. 2004-34126-14388. We thank W. Newall and S. Hudson for field work assistance and W. Bridges for statistical advice.

\section{LITERATURE CITED}

1. Adaskaveg, J. E., Forster, H., Wade, L., Thompson, D. F., and Connell, J. H. 1999. Efficacy of sodium tetrathiocarbonate and propiconazole in managing Armillaria root rot of almond on peach rootstock. Plant Dis. 83:240246.

2. Aguín, O., Mansilla, J. P., and Sainz, M. J. 2006. In vitro selection of an effective fungicide against Armillaria mellea and control of white root of grapevine in the field. Pest Manage. Sci. 62:223-228.

3. Appel, D. N., and Kurdyla, T. 1992. Intravascular injection with propiconazole in live oak for oak wilt control. Plant Dis. 76:1120-1124.

4. Baron, M. 1971. Dosage, migration d'un fongicide systémique (benomyl) dans les feuilles de bananier. Fruits 26:643-650.

5. Birchmore, R. J., Williams, R. J., and Russell, P. E. 1996. A baseline for the sensitivity of Botrytis cinerea to pyrimethanil. Brighton Crop Prot. Conf. Pests Dis. 1:713-719.

6. Bromilow, R. H., Evans, A. A., and Nicholls, P. H. 1999. Factors affecting degradation rates of five triazole fungicides in two soil types: 1. Laboratory incubations. Pestic. Sci. 55:11291134.

7. Bussey, K. E. 2006. Armillaria root rot: characterization of species infecting daylily and evaluation of intravascular chemical application for management. Thesis (M.S), Clemson University, Clemson, SC.

8. Chandler, W. A., and Daniel, J. W. 1982. Observations on long-term survival of Clitocybe tabescens and infection of peach trees. Research Report 399, University of Georgia, College of Agriculture, Griffin.

9. Chollet, J. F., Rocher, F., Jousse, C., DelétageGrandon, C., Bashiardes, G., and Bonnemain, J. L. 2005. Acid derivatives of fungicide fenpiclonil: effect of adding a methyl group to the $\mathrm{N}$-substituted chain on systemicity and fungicidal activity. Pest Manage. Sci. 61:377-382.

10. Elliston, J. E., and Walton, G. S. 1979. Distribution and persistence of methyl 2benzimidazole carbamate phosphate injected into American elms in late spring or early fall.
Phytopathology 69:1235-1239.

11. Filer, T. H., Jr. 1973. Pressure apparatus for injecting chemicals into trees. Plant Dis. Rep. 57:338-340.

12. Filip, G. M., and Roth, L. F. 1977. Stump injections with soil fumigants to eradicate $\mathrm{Ar}$ millaria mellea from young-growth ponderosa pine killed by root rot. Can. J. For. Res. 7:226231.

13. Garrett, S. D. 1957. Effect of soil microflora selected by carbon disulphide fumigation on survival of Armillaria mellea in woody host tissues. Can. J. Microbiol. 3:135-149.

14. Godfrey, G. H. 1936. Control of soil fungi by soil fumigation with chloropicrin. Phytopathology 26:246-259.

15. Guest, D. I., Pegg, K. G., and Whiley, A. W. 1995. Control of Phytophthora diseases of tree crops using trunk-injected phosphonates. Hortic. Rev. 17:300-330.

16. Heaton, J. B., and Dullahide, S. R. 1990 Efficiency of phosphonic acid in other pathogen systems. Aust. J. Plant Pathol. 19:133-134.

17. Helson, B. V., Lyons, D. B., Wanner, K. V., and Scarr, T. A. 2001. Control of conifer defoliators with neem-based systemic bioinsecticides using a novel injection device. Can. Entomol. 133:729-744.

18. Intrieri, C., and Ryugo, K. 1972. Enhanced penetration and translocation of a fungicide following foliar treatments of seedlings with growth retardants. Plant Dis. Rep. 56:590-592.

19. Jacob, F., and Neumann, St. 1987. Principles of uptake and systemic transport of fungicides within plant. Pages 13-26 in: Modern Selective Fungicides, Properties Applications and Mechanisms of action. H. Lyr, ed. VEB Gustav Fischer, Jena, Germany 1987 copublished in the United States with John Wiley \& Sons, New York.

20. Lacy, G. H. 1982. Peach X-disease: treatment site damage and yield response following antibiotic infusion. Plant Dis. 66:1129-1133.

21. Neumann, St., Grimm, E., and Jacob, F. 1985. Transport of xenobiotics in higher plants. I. Structural prerequisites for transportation in the phloem. Biochem. Physiol. 180:257-268.

22. Ouimette, D. G., and Coffey, M. D. 1990 Symplastic entry and phloem translocation of phosphonate. Pestic. Biochem. Physiol. 38:1825.

23. Osterbauer, N. K., and French, D. W. 1992. Propiconazole as a treatment for oak wilt in Quercus rubra and Q. ellipsoidalis. J. Arboric. 18:221-226.

24. Pinkas, Y., Shabi, E., Solez, Z., and Cohen, A. 1973. Infiltration and translocation of thiabendazole in apple trees by means of a pressure injection technique. Phytopathology 63:11661168

25. Rhoads, A. 1954. Clitocybe root rot found widespread and destructive in Georgia and South Carolina peach orchards. Plant Dis. Rep. 38:42-46.

26. Savage, E. F., Hayden, R. A., and Futral, J. G. 1974. Effect of soil fumigants on growth yield, and longevity of Dixired peach trees. Res. Bull. 148, Department of Horticulture, University of Georgia, Griffin.

27. Schnabel, G., Ash, J. S., and Bryson, P. K. 2005. Identification and characterization of Armillaria tabescens from the southeastern United States. Mycol. Res. 109:1208-1222.

28. Shamoun, S. F., and Sieber, T. N. 1993. Isozyme and protein-patterns of endophytic and disease syndrome-associated isolates of Melanconium apiocarpum and Melanconium marginale collected from alder. Mycotaxon 49:151-166.

29. Sherman, W. B., and Beckman, T. G. 1999. Armillaria root rot in peaches is controlled by methyl bromide. Proc. Fla. State Hortic. Soc. 112:190-191.

30. Smith, P. H., Chamberlain, K., Sugars, J. M., 
and Bromilow, R. H. 1995. Fungicidal activity of $\mathrm{N}$-(2-cyano-2-methoximinoacetyl) amino acids and their derivatives. Pestic. Sci. 44:219224.

31. Suzuki, M., Noshiro, S., Takahasi, A., Yoda, K., and Joshi. L., 1991. Wood structure of Himalayan plants. In: The Himalayan Plants. H. Ohba and S. B. Malla, eds. University of Tokyo Press, Tokyo.

32. Tattar, T. A., and Tattar, S. J. 1999. Evidence for the downward movement of materials in- jected into trees. J. Arboric. 25:325-332.

33. Thomas, H. E. 1934. Studies on Armillaria mellea (Vahl.) Quél. Infection, parasitism and host resistance. J. Agric. Res. 48:187-218.

34. Thorstensen, C. W., and Lode, O. 2001. Organic compounds in the environment: laboratory degradation studies of bentazone, dichlorprop, MCPA, and propiconazole in Norwegian soils. J. Environ. Qual. 30:947-953.

35. Weinke, K. E., Lauber, J. J., Greenwald, B. W., and Preiser, F. A. 1969. Thiabendazole, a new systemic fungicide. Proc. Br. Insectic. Fungic. Conf. 5th 2:340-346.

36. Zamora, M. A., and Escobar, R. F. 2000. Injector-size and the time of application affects uptake of tree trunk-injected solutions. Sci. Hortic. 84:63-177.

37. Zeller, S. M. 1926. Observations of infection of apple and prune roots by Armillaria mellea Vahl. Phytopathology 16:479-484.

38. Zimmerman, M. H. 1983. Xylem Structure and the Ascent of Sap. Springer-Verlag, New York. 